\title{
The Impact of Socio-Economic Factors on the Size of the External Plot Patchwork - a Case Study of Brzustowiec Village, in the Eódzkie Voivodship
}

\section{Introduction}

The presence of the plot patchwork is one of the significant factors that have a negative impact on the organization and the level of agricultural production. These plots are located in the area of the village in which they their owners live, but they can also be located outside this territory. In most cases, the reason for this is the fact of migration of rural residents in the direction of larger cities, which are centers of administrative, industrial and cultural services and educational and employment sources. Non-resident owners are mostly inheritors of parents living in the village, or of people who migrated to the cities. It should be, however, mentioned of the owners, who bought building plots in rural areas because of the great location and low prices, but they do not have family roots in the analyzed village [3].

According to many authors the plot patchwork is one of the significant factors that have negative impact on the organization and the level of agricultural production. Researchers studying this phenomenon found, that with the increase of the number of fields and their distance from the farm the intensity of agricultural production decreases, production costs increase, and in consequence a decrease of production and farm income takes place $[1,5]$. In terms of unfavorable geometry of the borders of plots, characterized by high fragmentation of land, the plot patchwork is also an impediment on the way of building a cadastral system in Poland. The occurrence of the plot patchwork is particularly evident in south and south-eastern Poland. For example - a comprehensive study of the spatial structure of land in the area $[2,3]$ have shown that every fourth parcel in Brzozowski district, of land owned by private individuals, lies in the external plot patchwork. On the other

* University of Life Sciences in Lublin, Department of Environmental Engineering and Geodesy, Lublin, Poland

** University of Agriculture in Krakow, Faculty of Environmental Engineering and Land Surveying, Department of Land Surveying, Krakow, Poland 
hand, in the village Będziemyśl located in the district Ropczyce-Sędziszów, every fifth plot is owned by non-resident owners [4]. Approximate values indicate that in Poland there are about 3 million hectares of agricultural land in a patchwork of plots.

The purpose of this article is further research on determination of the size of the external plot patchwork of individual farms land, in respect of the lesser known areas of the central Poland. The case study covers the area of Brzustowiec village, in the Opoczno district, in the Łódź region.

\section{Characteristics of the Object Based on Selected Criteria}

\subsection{Geographical Location, Landscape Features, Climate, Soils}

Brzustowiec village is located in the Łódź region, in the Opoczno district, in the municipality of Drzewica. The area of the village is 825.78 ha, which represents $7.0 \%$ of the total municipal area. The test area is characterized by a favorable position in relation to communication routes. It has a rich history and tradition.

The study area on the one hand is characterized by a landscape value, a large forest cover, clean environment, the presence of numerous rivers and the functioning of the lagoon, generating good conditions for fishing. In the area of the study a mountain slalom kayaking track is functioning - the only one in Poland, situated in the lowlands - which is an attraction for tourists.

On the other hand, the attention should be paid to the factors adversely affecting the region's development, such as: air pollution, mainly from low emissions from households and from roads, insufficient use of renewable energy sources associated with low public environmental awareness, resulting from the significant impoverishment and lack of private funds for the modernization of farms. Situation is exacerbated by the fact that there are weak soils and the associated with it lack of prospects for the development of more profitable agriculture.

\subsection{Demographic Factors}

Table 1 shows very little diversified pace of changes in population number in the area of research. It is noted, however, that the total population is gradually decreasing.

The society of the micro-region is classified as "aging" one. In addition, there is a relatively low level of education of residents there. An emergency situation is aggravated by the fact of the growth in the number of unemployed, including the long-term ones (more and more of them - persons under 25 years of age). Municipalities are forced to incur a significant amount of expenditure on social assistance. The difficult financial situation causes aggravation of the social pathologies. In addition, there is little activity of the large part of society. 
Table 1. Characteristics of changes in population in the study area

\begin{tabular}{||c|c|c||}
\hline Year & $\begin{array}{c}\text { Number of } \\
\text { inhabitants }\end{array}$ & $\begin{array}{c}\text { Dynamics of } \\
\text { changes [\%] }\end{array}$ \\
\hline \hline 2004 & 757 & - \\
\hline 2005 & 777 & 2.57 \\
\hline 2006 & 769 & -1.04 \\
\hline 2007 & 769 & 0.00 \\
\hline 2008 & 772 & 0.39 \\
\hline 2009 & 775 & 0.39 \\
\hline 2010 & 766 & -1.17 \\
\hline 2011 & 766 & 0.00 \\
\hline 2012 & 765 & -0.13 \\
\hline 2013 & 763 & -0.26 \\
\hline 2014 & 771 & 1.04 \\
\hline 2015 & 771 & 0.00 \\
\hline
\end{tabular}

Source: own calculations, based on [6]

\subsection{The Structure of Possession}

In terms of the structure of possession research, the subject land is dominated by individual farms. Their area is 610.66 hectares, which constitutes $74.0 \%$ of the total area of the village. There is a high percentage of lands of the Treasury, in particular there, State Forests National Forest Holding, which covers an area of 155.41 ha, which constitutes $18.8 \%$ of the total area of the village (Fig. 1).

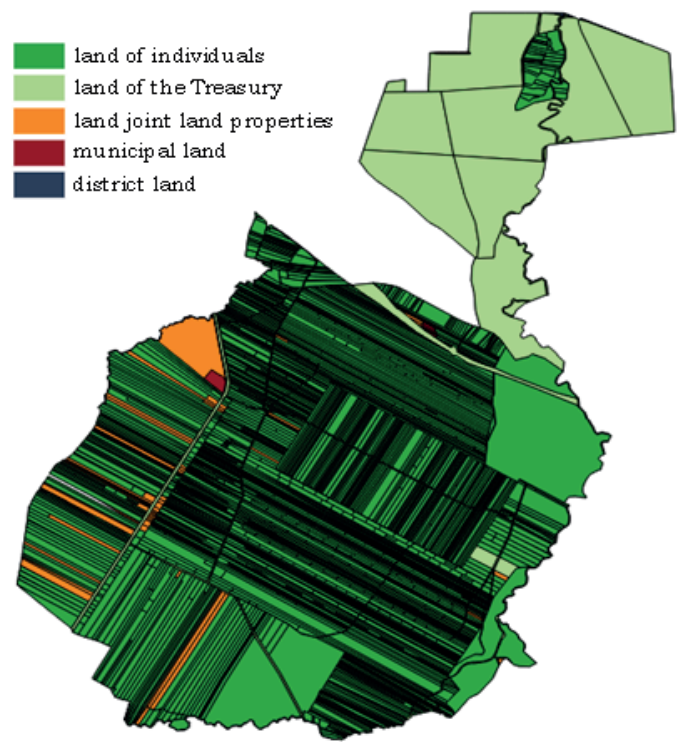

Fig. 1. Structure of the possession in the village Brzustowiec Source: study based on [7] 


\subsection{Land Use Structure}

In the structure of land use of Brzustowiec village dominates rural farmland, which together occupy 495.6 ha, which represents $60.02 \%$ of the total area of the village. Among agricultural land dominates arable land with an area of 411.8 ha, which represents $83.1 \%$ of agricultural land. A high percentage is covered by forests and their area of 294.3 ha what represents $35.6 \%$ of the village area. The spatial picture of the use structure is illustrated in Figure 2.

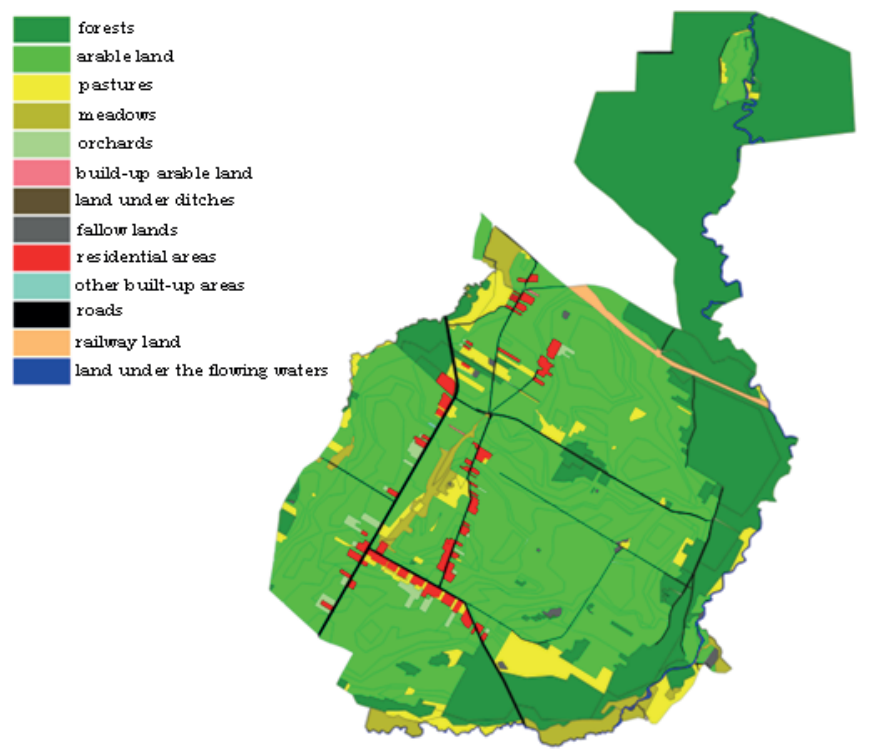

Fig. 2. The use structure in the village Brzustowiec

Source: study based on [7]

\subsection{Fragmentation of Land}

As can be seen in Table 2, the average plot size in the private sector is 0.31 ha. In the smallest range covering plots with surface $0.00-0.10$ ha, there were 600 parcels representing $31.33 \%$ of all parcels of natural persons, and their area is 34,14 ha which represents $5.59 \%$ of the total area of farms farms and is the smallest area of all intervals. Most numerous in terms of the number of plots is the interval, which covered the plots from 0.11 ha to 0.30 ha - these plots were as many as $790(41.25 \%$ of the individual sector plots) with the area of 141.40 ha (or 23.16\%). Next is the range of $0.31-0.60$ ha which includes 290 plots with an area of 119.74 ha. It represents $15.14 \%$ of all parcels and $19.61 \%$ of the area belonging to natural persons. Next, there is the interval including plots from 0.61 ha to $1.00 \mathrm{ha}$ - such plots were included into the analysis of 118 (6.16\% of the individual sector plots) with the total area of 92.88 ha 
which gives $15.21 \%$ of the individual farms area. The last interval includes the plots with area exceeding 1 ha. It is the least numerous in terms of the number of plots (117 plots, $6.11 \%$ ) but the largest in terms of area of plots which is 222.51 ha and this is $36.44 \%$ of the total area of the private sector. In addition, this interval has the highest average size of the plot at the level of 1.90 ha. Spatial image of the fragmentation of the plots is illustrated in Figure 3.

Table 2. The structure of the fragmentation of Brzustowiec village

\begin{tabular}{|c|c|c|c|c|c|c||}
\hline \multirow{2}{*}{ No. } & Area intervals [ha] & \multicolumn{2}{|c|}{ Plots } & \multicolumn{2}{|c|}{ Area } & $\begin{array}{c}\text { The average } \\
\text { plot size in the } \\
\text { interval [ha] }\end{array}$ \\
\cline { 5 - 7 } & number & {$[\%]$} & {$[\mathrm{ha}]$} & {$[\%]$} & 0.05 \\
\hline \hline 1 & $0.00-0.10$ & 600 & 31.3 & 34.1 & 5.6 & 0.17 \\
\hline 2 & $0.11-0.30$ & 790 & 41.2 & 141.4 & 23.2 & 0.41 \\
\hline 3 & $0.31-0.60$ & 290 & 15.1 & 119.7 & 196 & 0.78 \\
\hline 4 & $0.61-1.00$ & 118 & 6.2 & 92.8 & 15.2 & 1.90 \\
\hline 5 & $\geq 1.01$ & 117 & 6.1 & 222.5 & 36.4 & 0.31 \\
\hline
\end{tabular}

Source: study based on [7]

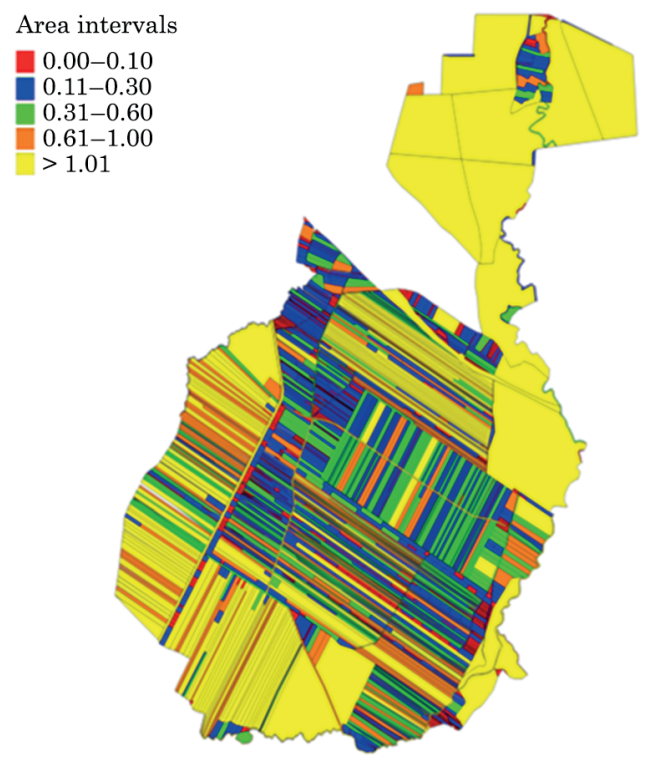

Fig. 3. The structure of fragmentation of the whole Brzustowiec village Source: study based on [7] 


\subsection{Prospects for the Development of the Region and Their Impact on the Expected Size of the Land Patchwork}

On the basis of the analyzes in sections 2.1-2.4 it can be concluded that the size and shape of the land patchwork are affected by a variety of socio-economic factors. The decisive role in this process is the land inheritance factor associated with the increasing migration of the non-resident owners beyond the boundaries of municipalities, districts and sometimes even the country, without their willingness to sell the land. On the one hand this is a factor favorably promising for the future, showing the attachment of the owners to the land and their desire to return to their homeland when the living conditions improve.

On the other hand, it interferes with the pace of some investment activities in the region, due to the inability of such owners to appear on the ground. Perspectives for the development are included in the document The development strategy of the Drzewica municipality and city [Annex No. 1 to Resolution No. IV/21/2014] for the years 2015-2020. The strategic objective of the study area is to provide residents of the Drzewica Municipality and the City conditions for a high standard of living. The population in the study area gradually decreases, unemployment increases, and the maintenance from the agriculture (on poor soils) is not cost-effective. The high average age of residents creates another problem. The chances to develop the region are its landscapes and good tourist facilities. These factors suggest that in the nearest future the external patchwork of land can develop further in the directions of big cities.

\section{Detailed Studies of the Spatial Structure of the Non-Resident Owners Land}

At the first the area of study was divided according to place of living of non-resident owners. In this way five groups of persons were created:

1) non-resident residing in the studied municipality,

2) non-resident owners residing in the same district,

3) non-resident owners residing in the same voivodship,

4) non-resident owners residing in the outside the voivodeship,

5) non-resident owners with the titles of co-ownership.

The results of a detailed spatial analysis are shown in Table 3. The analysis showed that the non-local owners amounts to 145.41 ha, which represents $23.8 \%$ of the total land area of individual farms. This group is formed by 172 owners who use 516 registration plots, which represents $26.9 \%$ of the total number of plots belonging to the owners of the private sector. Research has shown that the largest share in the scattering of the structure of the analyzed village have the owners coming 
from the Drzewica municipality. This number ranges from 1 owner from the Brzuza, Krzczonów, Radzice Małe, Werówka villages up to 65 owners from the municipal city Drzewica. The owners from the municipality Drzewica have 250 parcels with an area of 65.54 ha and their number varies from one plot in the village Brzuze, Krzczonów, Werówka to 155 plots belonging to the owners from the town of Drzewica. The area of that land constitutes $10.7 \%$ of the total area of the village.

Table 3. Land belonging to non-local owners in Brzustowiec village

\begin{tabular}{|c|c|c|c|c|c|c|c|}
\hline \multirow{2}{*}{$\begin{array}{c}\text { The area of land } \\
\text { of individual } \\
\text { farms [ha] }\end{array}$} & \multirow{2}{*}{$\begin{array}{l}\text { Number } \\
\text { of plots of } \\
\text { the private } \\
\text { sector }\end{array}$} & \multirow{2}{*}{$\begin{array}{l}\text { Land belonging } \\
\text { to non-local } \\
\text { owners }\end{array}$} & \multirow{2}{*}{$\begin{array}{c}\text { Number of } \\
\text { owners }\end{array}$} & \multicolumn{2}{|c|}{ Plots } & \multicolumn{2}{|c|}{ Area } \\
\hline & & & & number & {$[\%]$} & [ha] & [\%] \\
\hline \multirow{6}{*}{610.66} & \multirow{6}{*}{1915} & municipality & 102 & 250 & 13.1 & 65.5 & 10.7 \\
\hline & & district & 8 & 36 & 1.9 & 7.3 & 1.2 \\
\hline & & voivodship & 13 & 77 & 4.0 & 12.3 & 2.0 \\
\hline & & $\begin{array}{l}\text { outside the } \\
\text { voivodship }\end{array}$ & 29 & 103 & 5.4 & 33.1 & 5.4 \\
\hline & & co-ownerships & 20 & 50 & 2.6 & 27.2 & 4.4 \\
\hline & & total & 172 & 516 & 26.9 & 145.4 & 23.8 \\
\hline
\end{tabular}

Source: own study based on [7]

Quite a big impact on spatial structure in the area of research, have also non-resident owners from outside the Łódzkie Voivodship, which may result from the close to border position of Brzustowiec in the vicinity of Mazowieckie and Świętokrzyskie Voivodships. The number of these owners is 29 people. They are in possession of 103 parcels on the area of 33.1 ha, which represents $5.4 \%$ of the number of plots and plots of land of natural persons. The smallest group is from the Opoczno district because these are only 8 owners possessing 36 plots of 7.3 ha, which accounts for just over $1 \%$ of the non-resident owners land area. Slightly more on the other hand are the owners from the Łódzkie Voivodship, which are 13 persons and they possess 77 registration plots what makes $4.0 \%$ of all natural persons parcels. Land of non-resident owners, having co-ownership accounts for 50 parcels, with the total area of 27.2 ha, which is $4.4 \%$ of the total land area of non-resident owners. Spatial image of non-resident owners land is illustrated in Figure 4. 


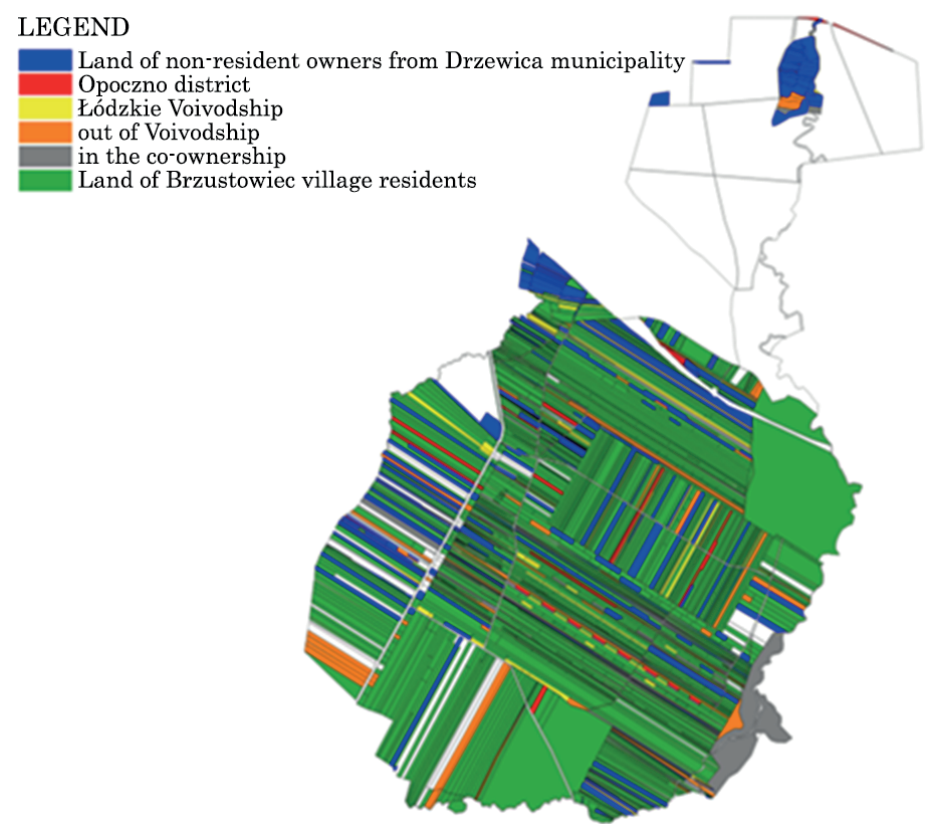

Fig. 4. Spatial image of non-resident owners land in Brzustowiec village Source: study based on [7]

\section{Conclusions}

The process of formation of the external plot patchwork is a continuous one, closely related to the demographic development of the population and the introduction of certain administrative, socio-economic and cultural systems. According to Noga [5] intervillage patchwork was created in the process of development caused by the operation of the following main factors:

- consolidating administrative borders of the village during the preparation of the first cadastral maps and subsequent changes,

- double inheritance of the land (from mother and father lines under Austrian Partition),

- marriage affinities,

- civil law circulation of land,

- parceling out large property estates in the interwar period,

- settlement in the Regained Lands,

- migration of rural population to urban industrial centres after World War II,

- the acquisition of rural land by urban residents, first for leisure - recreational buildings, and currently for residential buildings.

Research has shown that analyzed precinct has a very big external land patchwork. In Brzustowiec village 516 parcels is owned by non-resident owners, which 
represents $26.9 \%$ of the total number of plots of individual farms land. Their area amounts $145.4 \mathrm{ha}$, or $23.8 \%$ of the private land. One of the ways to eliminate this negative phenomenon can be exchange of agricultural land between the owners, what may affect the elimination of the unfavorable external land patchwork. Perfect instrument to achieve this objective introduces the law of 26 March 1982 about consolidation and exchange of land, which is regulated there procedure of land exchanging.

\section{References}

[1] Blohm G.: Ogólna ekonomika i organizacja gospodarstwa rolniczego. Państwowe Wydawnictwo Rolnicze i Leśne, Warszawa 1965.

[2] Leń P.: Rozmiary gruntów różniczan i możliwości ich likwidacji (na przykładzie wsi w powiecie Brzozów, województwo podkarpackie). [in:] XVII Ogólnopolska Konferencja "Nowe tendencje w teorii i praktyce urzadzania obszarów wiejskich" na temat "Rozwój obszarów wiejskich - stan obecny i perspektywy", Puławy 2426.06.2009, pp. 73-78.

[3] Leń P.: Prawidłowości w rozmiarze występowania gruntów różniczan zamiejscowych na przykładzie wsi w powiecie Brzozów. Infrastruktura i Ekologia Terenów Wiejskich, nr 1/II, 2012, pp. 137-145.

[4] Leń P., Matysek I., Kovalyshyn O.: Dimensions of Plots Belonging to Out-of-village Owners in the Village of Będziemyśl, Commune of Sędziszów Małopolski. Geomatics and Environmental Engineering, vol. 9, no. 2, 2015, pp. 63-70.

[5] Noga K.: Analiza międzywioskowej szachownicy gruntów na przykładzie wsi położonych w górnym dorzeczu Soły. Zeszyty Naukowe Akademii Rolniczej nr 133, Sesja Naukowa nr 7, Kraków 1977, s. 153-170.

[6] Strategia rozwoju gminy i miasta Drzewica na lata 2015-2020. Załacznik nr 1 do Uchwały nr IV/21/2014 Rady Gminy i Miasta w Drzewicy z dnia 30 grudnia 2014 r. [on-line:] http://www.drzewica.pl/sites/default/files/zalacznik_nr_1_ do_uchwaly_nr_iv-21-2014_0.pdf [access: 10.02.2016].

[7] Skorus J.: Analiza struktury przestrzennej obszarów wiejskich w Polsce centralnej na przykładzie wsi Brzustowiec, województwo łódzkie. Wyższa Szkoła Inżynieryjno-Ekonomiczna w Rzeszowie, Rzeszów 2016 [engineering thesis]. 